\title{
Factors associated to Theileria equi in equids of two microregions from Rio de Janeiro, Brazil
}

Fatores associados à Theileria equi em equídeos de duas microrregióes do Rio de Janeiro, Brasil

Tiago Marques dos Santos ${ }^{1 *}$; Erica Cristina Rocha Roier ${ }^{1}$; Huarrisson Azevedo Santos ${ }^{1}$; Marcus Sandes Pires ${ }^{1}$; Joice Aparecida Rezende Vilela ${ }^{1}$; Larissa Martins de Brito Moraes²; Fernando Queiroz de Almeida ${ }^{3}$; Cristiane Divan Baldani ${ }^{3}$; Rosangela Zacarias Machado ${ }^{4}$; Carlos Luiz Massard ${ }^{5}$

${ }^{1}$ Curso de Pós-Graduação em Ciências Veterinárias, Universidade Federal Rural do Rio de Janeiro - UFRRJ

${ }^{2}$ Graduação em Medicina Veterinária, Universidade Federal Rural do Rio de Janeiro - UFRRJ

${ }^{3}$ Departamento de Medicina e Cirurgia Veterinária, Instituto de Veterinária, Universidade Federal Rural do Rio de Janeiro - UFRRJ

${ }^{4}$ Departamento de Patologia Veterinária, Faculdade de Ciências Agrárias e Veterinárias, Universidade Estadual Paulista - UNESP

${ }^{5}$ Departamento de Parasitologia Animal, Instituto de Veterinária, Universidade Federal Rural do Rio de Janeiro - UFRRJ

Received January 31, 2011

Accepted March 14, 2011

\begin{abstract}
Serum samples from 714 equids of Itaguaí and Serrana microregions, Rio de Janeiro, southeastern Brazil, were examined by indirect fluorescent antibody test (titer 1:80) for Theileria equi. The prevalence in the microregions and factors associated with seropositivity were evaluated and the prevalence ratio (PR) calculated. The overall prevalence of T. equi infection was $81.09 \%(\mathrm{n}=579)$, with higher prevalence $(\mathrm{p}<0.05)$ in the Itaguaí $(85.43 \%)$ when compared to Serrana microregion $(76.92 \%)$. The geographic area, altitude, farming condition and area of origin of equids were associated $(\mathrm{p}<0.05)$ with seropositivity for T. equi. Equids reared in the Itaguaí microregion $(\mathrm{PR}=1.11, \mathrm{p}=0.003)$ and at altitudes below $500 \mathrm{~m}(\mathrm{PR}=1.10 ; \mathrm{p}=0,014)$ were more likely to be seropositive for $T$. equi. Furthermore, when equids were born in the farm $(P R=1.10, p=0.008)$ and reared with poor farming conditions $(P R=1.13$, $\mathrm{p}=0.018$ ) they were more likely to be exposed to T. equi. The main ticks found on equids were Amblyomma cajennense and Dermacentor (Anocentor) nitens. The microregions studied are endemic areas for equine theileriosis and there exists enzootic stability for T. equi. Only factors related to the collection area of serum samples influenced the seropositivity of equids for T. equi in that region.
\end{abstract}

Keywords: horses, equine theileriosis, IFAT, prevalence, epidemiology.

\section{Resumo}

Amostras de soro de 714 equídeos das microrregiôes de Itaguaí e Serrana, Rio de Janeiro, Brasil, foram submetidas ao teste de imunofluorescência indireta (título 1:80) para Theileria equi. A prevalência entre as microrregióes e os fatores associados à soropositividade foram avaliados e a razão de prevalência (RP) calculada. A prevalência geral para T. equi foi de $81,09 \%(\mathrm{n}=579)$, com maior prevalência $(\mathrm{p}<0,05)$ para microrregiāo de Itaguaí $(85,43 \%)$, quando comparado a Serrana $(76,92 \%)$. A regiáo, altitude, nível da propriedade e origem dos equídeos foram associados $(\mathrm{p}<0,05)$ com a soropositividade para T. equi. Equídeos criados na microrregião de Itaguaí $(\mathrm{RP}=1,11 ; \mathrm{p}=0,003)$ e em altitudes abaixo de $500 \mathrm{~m}(\mathrm{RP}=1.10 ; \mathrm{p}=0,014)$ apresentaram maior chance de se tornarem soropositivos para T. equi. Além disso, quando são criados em propriedades de nível ruim $(\mathrm{RP}=1,13 ; \mathrm{p}=0,018)$ e nascidos na propriedade $(\mathrm{RP}=1,10$; $\mathrm{p}=0,008)$ apresentaram mais chance de terem contato com T. equi. As principais espécies de carrapatos encontradas parasitando os equídeos foram Amblyomma cajennense e Dermacentor (Anocentor) nitens. As microrregiôes estudadas são endêmicas para theileriose equina e de estabilidade enzoótica para T. equi. Apenas os fatores relacionados à área de coleta das amostras de soro influenciaram a soropositividade dos equídeos para T. equi naquela região.

Palavras-chave: equinos, theileriose equina, RIFI, prevalência, epidemiologia.

\footnotetext{
*Corresponding author: Tiago Marques dos Santos

Curso de Pós-Graduação em Ciências Veterinárias,

Universidade Federal Rural do Rio de Janeiro - UFRRJ, BR 465, Km 7,

Antiga Estrada Rio-São Paulo, CEP 23890-000, Seropédica - RJ, Brazil;

e-mail: tiagorural@gmail.com
} 


\section{Introduction}

Equine theileriosis, also known as equine piroplasmosis, is a disease caused by Theileria equi, an intraerythrocytic parasite that infects equids. This agent is biologically transmitted by ixodid ticks (THOMPSON, 1969). In Brazil, T. equi is transmitted transstadially and intrastadially by Rhipicephalus (Boophilus) microplus (GUIMARÁES et al., 1998; UETI et al., 2005, 2008). Theileria equi can also be transmitted iatrogenically through infected blood (TENTER; FRIEDHOFF, 1986), transplacentally (ALLSOPP et al., 2007) and congenitally (SANTOS et al., 2008). Clinical signs of the disease in equids are fever, intravascular hemolysis, anemia, icterus, hemoglobinuria, edema, depression and even death (DE WALL, 1992). The severity of clinical signs is variable, and in many cases spontaneous recovery may occur without manifest clinical signs, especially in endemic areas (RIBEIRO et al., 1995).

Equine theileriosis has a worldwide distribution and is endemic in most tropical and subtropical areas as well as in some temperate regions (DE WAAL, 1992). This distribution is closely related to areas of higher concentration of vector ticks (FRIEDHOFF, 1988). In Brazil, equine theileriosis is endemic and the identification of risk factors associated with $T$. equi infection may play a role in the adoption of control measures. Moreover, epidemiological evidence may help better understand the mechanisms by which T. equi is spread in the host population.

Studies have reported the association of tick infestation (KERBER et al., 2009), age (RIBEIRO et al., 1999; RÜEGG et al., 2007; KOUAM et al., 2010), breed system BOTTEON et al., 2002; MORETTI et al., 2010), horse farm activity, geographic area, season of the year and geldings (SHKAP et al., 1998; RÜEGG et al., 2007; KOUAM et al., 2010; MORETTI et al., 2010) with T. equi infection. However, other factors may be associated to infection because the epidemiological characteristics of disease may differ between regions.

The present study aimed to determine the prevalence of T. equi in equids and whether there exists enzootic stability for T. equi in the microregions studied and to identify factors associated with seropositivity in equids.

\section{Materials and Methods}

The study was carried out in the Itaguaí and Serrana microregions in the State of Rio de Janeiro, southeastern Brazil, between January and May 2009. Non-probability convenience sampling was used. Overall, 714 equids (702 horses and 12 mules), 350 from the Itaguaí microregion (Itaguaí, $\mathrm{n}=116$; Mangaratiba, $\mathrm{n}=90$; and Seropédica $\mathrm{n}=144$ ) and 364 from the Serrana microregion (Petrópolis, $\mathrm{n}=192$; and Teresópolis $\mathrm{n}=172$ ) were examined and blood and ticks were collected. The altitude was recorded at each collection site with the use of Global Positioning System (GPS). An epidemiological questionnaire was applied to identify factors associated with seropositivity to T. equi (animal species, collection area, gender, age, altitute, equids farm activity, area of origin of equids, parasitism by ticks and flies).

Blood samples were collected by jugular venipuncture using a vacuum system and placed in sterile tubes without anticoagulant.
Serum samples were subsequently obtained by centrifugation at $6000 \mathrm{x} \mathrm{g}$ for 10 minutes and stored at $-20^{\circ} \mathrm{C}$ until serological analysis by indirect fluorescent antibody test (IFAT).

The horses and mules were inspected visually in the ears, head, neck, pectoral, armpit, inguinal and tail areas for identification of animals infested with ticks. In parasitized animals, the degree of infestation by each tick species was categorized according to Teglas et al. (2005) as: none, mild (1-20 ticks per animal), moderate (21-50 ticks per animals) or severe (more than 50 ticks per animal). Adult ticks were collected and stored in isopropyl alcohol for identification using an appropriate dichotomous key (BARROS-BATTESTI et al., 2006).

IFAT was performed using slides with partially purified antigen from Jaboticabal T. equi strain (GenBank accession nr. AF255730) previously prepared according to Baldani et al. (2007). For testing, the slides were incubated with each test serum, diluted at 1:80 in a humid chamber at $37^{\circ} \mathrm{C}$ for 45 minutes. After three washes in buffered saline (PBS), the slides were incubated with fluorescein isothiocyanate-conjugated equine anti-immunoglobulin G (SigmaAldrich $^{\oplus}$ ) diluted at 1:32 and examined under a fluorescence microscope (Hund Wetzlar, model H600/12, Germany). Serum samples with titers $\geq 80$ were considered positive. The positive control used was horse serum experimentally infected with Jaboticabal $T$. equi strain. The negative control used was horse serum free of infection by $T$. equi and $B$. caballi.

For statistical analysis, the following factors were analyzed: collection area (microregions and their municipalities); altitude ( $<500 \mathrm{~m}$; $\geq 500 \mathrm{~m}$ but < 800; and $\geq 800$ to $1004 \mathrm{~m}$ ); animal species (horse; mule); gender; age ( $<6$ months; 6-12 months; 1-3 years; $3-5$ years; 5-10 years; and $>10$ years); equids farm activity (sports, exhibition, recreation, farming, breeding and foals of undetermined activity); breeding systems (confined, semiconfined and extensive); close contact with cattle (yes; no); and area of origin of equids (inside or outside the farm). In addition to these factors, the farms were categorized into four levels based on farming conditions (i.e., farm infrastructure and management of animals) as follows: excellent (animals reared in stalls and paddocks, fed with forage and concentrate rations, systematic control of ticks, no tick infestation, frequent veterinary care); good (same as above, except for non-systematic tick control and tick infestation); moderate (animals reared in stalls and pasture, sporadic tick control, tick infestation, sporadic veterinary care) and poor (animals reared on pasture only, no tick control, tick infestation and no veterinary care).

The prevalence of T. equi infection in the microregions and the frequency of positive equids in other categories were calculated, and potential differences were assessed using the chi-square and Fisher's exact test at 5\% significance level. BioStat 4.0 was used to estimate the prevalence ratio (PR) for factors associated $(\mathrm{p}<0.05)$ with seropositivity to T. equi.

\section{Results}

The overall T. equi prevalence was $81.09 \%(\mathrm{n}=579)$ in the equids examined (Table 1). The Itaguaí microregion showed a higher prevalence $(\mathrm{p}<0.05)$ than that in the Serrana microregion, 
Table 1. Prevalence of anti-T. equi antibodies in equids in the Itaguaí and Serrana microregions in the State of Rio de Janeiro and factors associated to the collection area.

\begin{tabular}{|c|c|c|c|c|}
\hline \multirow[t]{2}{*}{ Factor } & \multirow[t]{2}{*}{$\mathbf{N}$} & \multicolumn{2}{|c|}{ Theileria equi } & \multirow[t]{2}{*}{ p value } \\
\hline & & $\mathbf{n}$ & $\%$ & \\
\hline Prevalence & 714 & 579 & 81.09 & \\
\hline \multicolumn{5}{|l|}{ Microregion } \\
\hline Serrana & 364 & 280 & $76.92^{\mathrm{b}}$ & \multirow{2}{*}{0.005} \\
\hline Itaguaí & 350 & 299 & $85.43^{\mathrm{a}}$ & \\
\hline \multicolumn{5}{|l|}{ Municipality } \\
\hline Itaguaí & 116 & 104 & $89.66^{a}$ & \multirow{5}{*}{0.021} \\
\hline Seropédica & 144 & 123 & $85.42^{\mathrm{a}}$ & \\
\hline Mangaratiba & 90 & 72 & $80.00^{\mathrm{a}}$ & \\
\hline Teresópolis & 172 & 133 & $77.33^{\mathrm{b}}$ & \\
\hline Petrópolis & 192 & 147 & $76.55^{\mathrm{b}}$ & \\
\hline \multicolumn{5}{|l|}{ Altitude (m) } \\
\hline$<500$ & 352 & 300 & $85.23^{\mathrm{a}}$ & \multirow{3}{*}{0.021} \\
\hline 500 to $<800$ & 163 & 125 & $76.69^{\mathrm{b}}$ & \\
\hline 800 to $<1004$ & 199 & 154 & $77.39^{\mathrm{b}}$ & \\
\hline \multicolumn{5}{|l|}{ Farming conditions } \\
\hline Excellent & 127 & 97 & $76.38^{\mathrm{b}}$ & \multirow{4}{*}{0.038} \\
\hline Good & 270 & 210 & $77.78^{\mathrm{b}}$ & \\
\hline Moderate & 134 & 114 & $85.07^{\mathrm{ab}}$ & \\
\hline Poor & 183 & 158 & $86.34^{\mathrm{a}}$ & \\
\hline \multicolumn{5}{|c|}{ Area of origin of equids } \\
\hline Inside the farm & 218 & 189 & $86.70^{a}$ & \multirow{2}{*}{0.015} \\
\hline Outside the farm & 496 & 390 & $78.63^{b}$ & \\
\hline
\end{tabular}

${ }^{a}$ Values followed by the same letters did not show any differences in the chi-square test at $5 \%$ significance level; $\mathrm{N}$ : number of animals examined by indirect fluorescent antibody test; $\mathrm{n}$ : number of seropositive animals.

$85.43 \%(\mathrm{n}=299)$ vs. $76.92 \%(\mathrm{n}=280)$ respectively. The microregions with their municipalities, altitude and farming conditions were associated $(\mathrm{p}<0.05)$ with the rate of $T$. equi antibodies (Table 1). Equids reared in the Itaguaí microregion and its municipalities $(\mathrm{PR}=1.11, \mathrm{p}=0.003)$ and at altitudes below $500 \mathrm{~m}(\mathrm{PR}=1.10 ; \mathrm{p}=0,014)$ were more likely to be seropositive for T. equi. Furthermore, when equids were born in the farm $(\mathrm{PR}=1.10, \mathrm{p}=0.008)$ and reared in poor farming conditions $(\mathrm{PR}=1.13, \mathrm{p}=0.018)$ they were more likely to be exposed to T. equi (Table 4).

Equid-related factors studied are presented in Table 2. There was no association ( $\mathrm{p}=0.544$ ) between positive serology and animal species, with $81.1 \%(\mathrm{n}=569)$ and $83.3 \%(\mathrm{n}=10)$ of positivity found in horses and mules, respectively. There was no association between gender $(p=0.581)$, age $(p=0.166)$, horse farm activity ( $\mathrm{p}=0.375)$, breeding system $(\mathrm{p}=0.279)$ and close contact between equids and cattle $(\mathrm{p}=0.388)$ and $T$. equi seropositivity. However, there was not found significantly higher prevalence of T. equi infection in equids used for exhibition $(85.1 \%, \mathrm{n}=40)$, breeding $(85.19 \%, \mathrm{n}=92)$, sports $(82.08 \%, \mathrm{n}=229)$ and foals with undetermined activity $(86.96 \%, \mathrm{n}=20)$ compared to those used for recreation and farming. There was found a trend for higher seropositivity in equids reared in semi-confined and extensive systems when compared to those bred in confined systems, with
Table 2. Prevalence of anti-T. equi antibodies in equids in the Itaguaí and Serrana microregions in the State of Rio de Janeiro and equidrelated factors.

\begin{tabular}{|c|c|c|c|c|}
\hline \multirow[t]{2}{*}{ Factor } & \multirow[t]{2}{*}{$\mathbf{N}$} & \multicolumn{2}{|c|}{ Theileria equi } & \multirow{2}{*}{$\underset{\text { value }}{p}$} \\
\hline & & n & $\%$ & \\
\hline Prevalence & 714 & 579 & 81.09 & \\
\hline \multicolumn{5}{|l|}{ Animal species } \\
\hline Horse & 702 & 569 & $81.05^{\mathrm{a}}$ & \multirow{2}{*}{0.432} \\
\hline Mule & 12 & 10 & $83.30^{\mathrm{a}}$ & \\
\hline \multicolumn{5}{|l|}{ Gender } \\
\hline Male & 416 & 334 & $80.29^{a}$ & \multirow{2}{*}{0.581} \\
\hline Female & 298 & 245 & $82.21^{\mathrm{a}}$ & \\
\hline \multicolumn{5}{|l|}{ Age } \\
\hline$<6$ months old & 30 & 27 & $90.00^{\mathrm{a}}$ & \multirow{6}{*}{0.166} \\
\hline 6-12 months old & 32 & 28 & $87.50^{\mathrm{a}}$ & \\
\hline $1-3$ years old & 85 & 70 & $82.35^{\mathrm{a}}$ & \\
\hline $3-5$ years old & 92 & 73 & $79.35^{\mathrm{a}}$ & \\
\hline 5-10 years old & 276 & 211 & $76.45^{\mathrm{a}}$ & \\
\hline$>10$ years old & 199 & 170 & $85.43^{\mathrm{a}}$ & \\
\hline \multicolumn{5}{|l|}{ Equids farm activity } \\
\hline Sports & 279 & 229 & $82.08^{a}$ & \multirow{6}{*}{0.375} \\
\hline Exhibition & 47 & 40 & $85.11^{\mathrm{a}}$ & \\
\hline Recreation & 146 & 111 & $76.03^{\mathrm{a}}$ & \\
\hline Farming & 111 & 87 & $78.38^{\mathrm{a}}$ & \\
\hline Breeding & 108 & 92 & $85.19^{a}$ & \\
\hline Foals of undetermined activity & 23 & 20 & $86.96^{a}$ & \\
\hline \multicolumn{5}{|l|}{ Breeding system } \\
\hline Confined & 52 & 38 & $73.08^{\mathrm{a}}$ & \multirow{3}{*}{0.279} \\
\hline Semi-confined & 498 & 405 & $81.33^{\mathrm{a}}$ & \\
\hline Extensive & 164 & 136 & $82.93^{\mathrm{a}}$ & \\
\hline \multicolumn{5}{|l|}{ Close contact with cattle } \\
\hline No & 521 & 427 & $81.96^{\mathrm{a}}$ & \multirow{2}{*}{0.388} \\
\hline Yes & 193 & 152 & $78.76^{\mathrm{a}}$ & \\
\hline
\end{tabular}

${ }^{a}$ Values followed by the same letters did not show any differences in the chi-square test at $5 \%$ significance level; $\mathrm{N}$ : number of animals examined by indirect fluorescent antibody test; n: number of seropositive animals.

a prevalence of $81.33 \%(\mathrm{n}=405), 82.93 \%(\mathrm{n}=136)$ and $73.08 \%$ $(\mathrm{n}=38)$, respectively.

Ticks collected parasitizing equids were identified as Amblyomma cajennense, Dermacentor (Anocentor) nitens and Rhipicephalus (Boophilus) microplus species. The latter species was found only in two horses and was not included in the analysis (Table 3). Parasitism by at least one of these species was observed in $82.54 \%$ $(\mathrm{n}=279)$ of the animals, however, no association ( $\mathrm{p}=0.399)$ with seropositivity was seen. Similarly, no association with the degree of infestation by $A$. cajennense and $D$. nitens with T. equi seropositivity was found. In both cases, there was no significantly higher rates of positive animals associated with increasing degrees of tick infestation. Moderate to severe infestation by $D$. nitens and $A$. cajennense tick was observed, respectively, in $17.09 \%$ $(\mathrm{n}=122)$ and $14.16 \%(\mathrm{n}=101)$ of the animals examined. The parasitism of equids by $A$. cajennense and $D$. nitens was more severe in the Itaguaí compared with the Serrana microregion. However, A. cajennense tick was widely distributed in both microregions 
Table 3. Prevalence of anti-T. equi antibodies in equids in the Itaguaí and Serrana microregions in the State of Rio de Janeiro and factors related to tick parasitism and Stomoxys calcitrans fly infestation.

\begin{tabular}{|c|c|c|c|c|}
\hline \multirow[t]{2}{*}{ Factor } & \multirow[t]{2}{*}{$\mathbf{N}$} & \multicolumn{2}{|c|}{ Theileria equi } & \multirow[t]{2}{*}{ p value } \\
\hline & & $\mathbf{n}$ & $\%$ & \\
\hline \multicolumn{5}{|l|}{ Tick infestation } \\
\hline No & 376 & 300 & $79.79^{\mathrm{a}}$ & \multirow{2}{*}{0.399} \\
\hline Yes & 338 & 279 & $82.54^{\mathrm{a}}$ & \\
\hline \multicolumn{5}{|c|}{$\begin{array}{l}\text { Degree of infestation } \\
\text { (Amblyomma cajennense) }\end{array}$} \\
\hline None & 376 & 300 & $79.79^{\mathrm{a}}$ & \multirow{4}{*}{0.576} \\
\hline Mild & 220 & 178 & $80.91^{\mathrm{a}}$ & \\
\hline Moderate & 76 & 65 & $85.53^{\mathrm{a}}$ & \\
\hline Severe & 42 & 36 & $85.71^{\mathrm{a}}$ & \\
\hline \multicolumn{5}{|c|}{$\begin{array}{l}\text { Degree of infestation } \\
\text { (Dermacentor nitens) }\end{array}$} \\
\hline None & 487 & 391 & $80.29^{\mathrm{a}}$ & \multirow{4}{*}{0.536} \\
\hline Mild & 78 & 66 & $84.62^{\mathrm{a}}$ & \\
\hline Moderate & 97 & 82 & $84.54^{\mathrm{a}}$ & \\
\hline Severe & 52 & 40 & $76.92^{\mathrm{a}}$ & \\
\hline \multicolumn{5}{|c|}{$\begin{array}{l}\text { Stomoxys calcitrans } \\
\text { infestation }\end{array}$} \\
\hline No & 425 & 343 & $80.71^{\mathrm{a}}$ & \multirow{2}{*}{0.824} \\
\hline Yes & 289 & 236 & $81.67^{\mathrm{a}}$ & \\
\hline \multicolumn{5}{|c|}{$\begin{array}{l}\text { aValues followed by the same letters did not show any differences in } \\
\text { the chi-square test at } 5 \% \text { significance level; N: number of animals } \\
\text { examined by indirect fluorescent antibody test; n: number of sero- } \\
\text { positive animals. }\end{array}$} \\
\hline
\end{tabular}

(data not shown). In addition to tick parasitism, fly infestation by Stomoxys calcitrans fly was seen in $81.67 \%(n=236)$ of horses. However, no association ( $\mathrm{p}=0.824$ ) was found between fly infestation and T. equi seropositivity.

\section{Discussion}

The prevalence of T. equi infection found in this study is corroborated by previous studies showing that equine theileriosis is endemic in the municipalities of the metropolitan mesoregion of Rio de Janeiro (PFEIFER BARBOSA et al., 1995; BITTENCOURT; MASSARD, 1997; BOTTEON et al., 2002; SANTOS et al., 2009). In these studies the prevalence of T. equi infection ranged from 73.6 to $100 \%$, which can be explained by differences in the number of equids examined and serological test used for diagnosis. Few studies have been conducted on equine theileriosis in the Serrana microregion of the state of Rio de Janeiro. Seropositivity for T. equi was seen in $21 \%(\mathrm{n}=52)$ of thoroughbred horses in an equestrian establishment in Teresópolis (DA COSTA PEREIRA et al., 2005) and 5.6\% $(\mathrm{n}=4)$ in Nova Friburgo (DA COSTA PEREIRA et al., 2007). The seroprevalence found in these studies is lower than that found in the Serrana microregion, 76.92\% $(\mathrm{n}=280)$ (Table 1). This inconsistency can be explained by a lower number of equids investigated in these studies, no distribution of sampling in the mountainous region and use of the complement fixation test (CFT) as a diagnostic method. According to Tenter and Friedhoff (1986) and Brüning (1996), the CFT is less sensitive than IFAT

Table 4. Prevalence ratio (PR) of anti-Theileria equi antibodies by IFAT* and factors associated with seropositivity in equids.

\begin{tabular}{|c|c|c|c|c|c|c|}
\hline \multirow[t]{2}{*}{ Factor } & \multirow[t]{2}{*}{$\mathbf{N}$} & \multicolumn{2}{|c|}{ Theileria equi } & \multirow[t]{2}{*}{ PR } & \multirow[t]{2}{*}{$95 \% \mathrm{CI}$} & \multirow[t]{2}{*}{ p-value } \\
\hline & & $\mathbf{n}$ & $\%$ & & & \\
\hline \multicolumn{7}{|l|}{ Microregion } \\
\hline Serrana & 364 & 280 & 76.92 & 1 & & \multirow{2}{*}{0.003} \\
\hline Itaguaí & 350 & 299 & 85.43 & 1.11 & 1.03 a 1.19 & \\
\hline \multicolumn{7}{|l|}{ Municipality } \\
\hline Petrópolis & 192 & 147 & 76.55 & 1 & & \\
\hline Seropédica & 144 & 123 & 85.42 & 1.12 & 1.01 a 1.24 & 0.030 \\
\hline Mangaratiba & 90 & 72 & 80.00 & 1.04 & 0.92 a 1.19 & 0.311 \\
\hline \multicolumn{7}{|l|}{ Altitude (m) } \\
\hline$<500$ & 352 & 300 & 85.23 & 1.10 & $1.01 \mathrm{a} 1.20$ & 0.014 \\
\hline 500 to $<800$ & 163 & 125 & 76.69 & 0.99 & 0.88 a 1.11 & 0.487 \\
\hline \multicolumn{7}{|l|}{ Farming conditions } \\
\hline Good & 270 & 210 & 77.78 & 1.02 & 0.91 a 1.14 & 0.428 \\
\hline Moderate & 134 & 114 & 85.07 & 1.11 & 0.99 a 1.26 & 0.052 \\
\hline Poor & 183 & 158 & 86.34 & 1.13 & $1.01 \mathrm{a} 1.27$ & 0.018 \\
\hline \multicolumn{7}{|c|}{ Area of origin of equids } \\
\hline Outside the farm & 496 & 390 & 78.63 & 1 & & \multirow{2}{*}{0.008} \\
\hline Inside the farm & 218 & 189 & 86.70 & 1.10 & 1.03 a 1.18 & \\
\hline
\end{tabular}

$\mathrm{N}$ : number of animals examined by indirect fluorescent antibody test (IFAT); n: number of seropositive animals; CI: confidence interval. 
and can produce false negative results in chronic infections by T. equi. Other studies reported a prevalence of T. equi infection similar to that found in the present study (BALDANI et al., 2004; XUAN et al., 2001; HEIM et al., 2007). However, the prevalence of T. equi infection reported in southern Brazil is lower than that reported in present study (CUNHA et al., 1996; SOUZA et al., 2000; NIZOLI et al., 2008; GOLYNSKI et al., 2008). This difference may be due to climate influence in the biological cycle of $R$. (B.) microplus in the southern region. Brum et al. (1987) demonstrated three generations of $R$. (B.) microplus per year in the municipality of Pelotas, southern Brazil. However, four generations of this tick have been reported in the southeastern region (MAGALHÂES; LIMA, 1991).

The association of altitude with seropositivity to T. equi shows that increasing altitudes can reduce the likelihood of horse infection. This can be explained by climate interference in the cycle of the tick vector at high altitudes. Higher seropositivity rates were seen in equids from inside the farm, reflecting specific characteristics of the farm including inadequate tick control or of other parasites that could reduce the risk of infection. As this is an endemic area for equine theileriosis and of enzootic stability for T. equi, horses brought from other regions or even countries may not yet have been infected.

Due to the small number of mules examined compared to horses, the lack of association between T. equi infection and animal species should not be generalized until a larger number of mules is investigated in further studies. The lack of association with gender is consistent with other studies (SHKAP et al., 1998; SOUZA et al., 2000; BOTTEON et al., 2002; KOUAM et al., 2010). However, a weak association $(\mathrm{p}<0.047, \mathrm{OR}=1.498)$ was reported by Moretti et al. (2010) that found a higher prevalence of anti-T. equi antibodies in females compared to males. Similar results were observed in the present study, however, without any significant association.

Foals younger than six months showed the highest frequency of T. equi antibodies when compared with older equids (Table 2). This can be explained in part by the presence of maternal antibodies, which can persist for three to five months (DONNELLY et al., 1982; HEUCHERT et al., 1999). Animals aged six to 12 months showed $87.5 \%(\mathrm{n}=28)$ of T. equi seropositivity. The absence of maternal antibodies in this group suggests that the first $T$. equi infection was between six and 12 months or younger, since there is no passive immunity over six months old. Thereafter, the frequency of antibodies remained stable with no significant increase in animals older than 10 years, $85.42 \%(\mathrm{n}=170)$. This may explain why the animals had no clinical signs of equine theileriosis, since once infected with T. equi, horses remain carriers throughout their lifetime (FRIEDHOFF, 1988; DE WALL, 1992) and are important reservoirs of this protozoan for tick vectors (UETI et al., 2008). The seroprevalence above $75 \%$ seen in animals aged six to 12 months indicate that there exists enzootic stability for T. equi in the microregions studied (MAHONEY; ROSS, 1972). The lack of association between age and seropositivity for T. equi is consistent with some reports in the literature (SHKAP et al., 1998; SOUZA et al., 2000; BOTTEON et al., 2002; MORETTI et al., 2010). However, other studies found inconsistent results (RIBEIRO et al., 1999; RÜEGG et al., 2007;
KOUAM et al., 2010). They could be explained in part by different age categorization. Furthermore, the association of age reported in the literature can be due to small numbers of animals in some categories, which can interfere in the analysis of the data.

Higher frequency of horses seropositive for T. equi was seen in those used for exhibition and sports. This can be explained by the stress and animal moving for training and competitions (HAILAT et al., 1997). Among those used for breeding, they may be more exposed to tick infestations since most are raised in extensive or semi-confined systems.

The non-significant increase in seropositivity of the equids reared in semi-confined $(75.6 \%, \mathrm{n}=124)$ and extensive $(13.9 \%, \mathrm{n}=69)$ systems can be explained by the fact that these animals have closer contact with cattle (data not shown) and consequently with when compared to those reared in confined systems. $R$. (B.) microplus tick is the only known biological vector that transmit T. equi in Brazil (GUIMARÃES et al., 1998) and the U.S. (UETI et al., 2005, 2008). Cattle are the primary host for $R$. (B.) microplus, and infestation of horses with this tick is dependent on the presence of cattle in the same area (LABRUNA et al., 2001). However, the presence of equids with cattle in the same area was not associated with seropositivity for T. equi, probably due to the fact that this was an enzootic stability area for this agent. Furthermore, other forms of transmission are possible, such as iatrogenically through infected blood (TENTER; FRIEDHOFF, 1986), transplacentally (ALLSOPP et al., 2007) and congenitally (SANTOS et al., 2008). Bloodsucking flies were also suggested vectors, but without confirmation. Similar findings were reported by Botteon et al. (2002), however, they reported differences $(\mathrm{p}<0.05)$ in T. equi seropositive horses when reared in confined systems. This difference was not observed in this study, which may be due to the small number of animals evaluated in this group.

The differences in tick parasitism between Itaguaí and Serrana microregions demonstrate their distinct edafoclimatic characteristics, which would influence the epidemiology of equine theileriosis. Evidence of parasitism by three tick species in this study is consistent with the results reported in studies conducted in Brazil (BORGES; LEITE, 1998; HEUCHERT et al., 1999; LABRUNA et al., 2001; DA COSTA PEREIRA et al., 2005; KERBER et al., 2009). Unlike in the present study, an association ( $\mathrm{p}<0.001$ ) between T. equi positivity and low infestation by D. nitens (mean lower than 10 adult ticks per animal) and high infestation by $A$. cajennense (mean higher than 10 adult ticks per animal) was found (KERBER et al., 2009). This disagreement can be explained by different categorization of degree of infestation. Also, the analysis was grouped by farms rather than by animals as we did in this study. Furthermore, $D$. nitens and $A$. cajennense are not able to transmit T. equi, which explains the lack of association with seropositivity of horses seen in present study and reported by Rüegg et al. (2007).

According to Kerber et al. (2009), A cajennense infestation is associated with $T$. equi infection and this tick could be a vector of this agent under natural conditions, though no experimental studies has evidenced that $A$. cajennense is a competent vector. This epidemiological indication is reinforced by the fact that all horses examined were young (6-24 months old), restricted to the farm area and never received blood or plasma transfusions. 
In addition, all farms reported the complete absence of any cattle for at least 36 months, which was a period longer than the age of the horses examined. Different from the reported by Kerber et al. (2009), most animals examined in the present study were older than 24 months and many of them have left the farm area for any reason. However, the possibility of $A$. cajennense and even $D$. nitens and $S$. calcitrans act as a vector of T. equi cannot be ruled out as it could explain in part the enzootic stability existing in the microregions studied.

Based on the study results, we conclude that $T$. equi infection is more prevalent in the microregion of Itaguai than Serrana. However, both microregions are endemic areas for equine theileriosis with enzootic stability for T. equi. Only factors related to the collection area influenced T. equi seropositivity in equids in that region in the state of Rio de Janeiro. These factors should be used for the development of programs for prevention and control of equine theileriosis.

\section{References}

ALLSOPP, M. T. E. P.; LEWIS, B. D.; PENZHORN, B. L. Molecular evidence for transplacental transmission of Theileria equi from carrier mares to their apparently healthy foals. Veterinary Parasitology, v. 148, n. 2, p. 130-136, 2007. PMid:17601669. http://dx.doi.org/10.1016/j. vetpar.2007.05.017

BALDANI, C. D. Serodiagnosis of Babesia equi in horses submitted to exercise stress. Pesquisa Veterinária Brasileira, v. 27 , n. 4 , p. 179-183, 2007.

BALDANI, C. D. et al. An enzyme-linked immunosorbent assay for the detection of IgG antibodies against Babesia equi in horses. Ciência Rural, v. 34, n. 5, p. 1525-1529, 2004.

BARROS-BATTESTI, D. M.; ARZUA, M.; BECHARA, G. H. Carrapatos de Importância Médico-Veterinária da Regiáo Neotropical: Um guia ilustrado para identificaçáo de espécies. São Paulo, 2006. 223 p.

BITTENCOURT, V. R. E. P.; MASSARD, C. L. Aspectos epidemiológicos da babesiose eqüina na Microregião Fluminense do Grande Rio-Itaguaí, Estado do Rio de Janeiro. Revista Brasileira de Ciências Veterinárias, v. 4, n. 1, p. 13-17, 1997.

BORGES, L. M. F.; LEITE, R. C. Fauna ixodológica do pavilhäo auricular de eqüinos em municípios de Minas Gerais e da Bahia. Arquivo Brasileiro de Medicina Veterinária e Zootecnia, v. 50, n. 1, p. 87-89, 1998.

BOTTEON, P. T. L. et al. Seroprevalencia de Babesia equi en tres diferentes sistemas de crianza de equinos: Rio de Janeiro, Brasil. Parasitologia Latinoamericana, v. 57, n. 3-4, p. 141-145, 2002.

BRÜNING, A. Equine piroplasmosis an update on diagnosis, treatment and prevention. British Veterinary Journal, v. 152, n. 2, p. 139-151, 1996. http://dx.doi.org/10.1016/S0007-1935(96)80070-4

BRUM, J. G. W. et al. Flutuação sazonal de Boophilus microplus (Canestrini, 1887) no município de Pelotas, RS. Arquivo Brasileiro de Medicina Veterinária e Zootecnia, v. 39, n. 6, p. 891-896, 1987.

CUNHA, C. W. et al. Avaliação da frequência de equinos soropositivos a Babesia equi no Jóquei Clube de Pelotas e em dois haras da zona sul do
Rio Grande do Sul, RS. Revista Brasileira de Parasitologia Veterinária, v. 5, n. 2, p. 119-122, 1996.

DA COSTA PEREIRA, M. A. V.; MASSARD, C. L.; VITA, G. F. Babesiose equina: Enzootia em Nova Friburgo, Rio de Janeiro, Brasil. Revista Portuguesa de Ciências Veterinárias, v. 102, n. 561-562, p. 165-167, 2007.

DA COSTA PEREIRA, M. A. V. et al. Variação da sorotitulação ao teste de fixação de complemento para Babesia equi e Babesia caballi em eqüinos da regiāo serrana do Rio de Janeiro. Ars Veterinaria, v. 21, n. 3 , p. 338-343, 2005.

DE WAAL, D. T. Equine piroplasmosis: a review. British Veterinary Journal, v. 148, n. 1, p. 6-14, 1992.

DONNELLY, J.; PHIPPS, L. P.; WATKINS, K. L. Evidence of maternal antibodies to Babesia equi and B. caballi in foals of seropositive mares. Equine Veterinary Journal, v. 14, n. 2, p. 126-128, 1982. PMid:7084196. http://dx.doi.org/10.1111/j.2042-3306.1982.tb02365.x

FRIEDHOFF, K. T. Transmission of Babesia. In: RISTIC, M. Babesiosis of domestic animals and man. Boca Raton: CRC Press, 1988. p. 23-52.

GOLYNSKI, A. A. et al. Estudo soroepidemiológico da Babesia equi em equinos do estado do Rio Grande do Sul, Brasil, determinado pelos testes de imunofluorescência indireta e Elisa. Revista Brasileira de Parasitologia Veterinária, v. 17, p. 317-321, 2008. Suplemento 1.

GUimarÁES, A. M.; LIMA, J. D.; RIBEIRO, M. F. Sporogony and experimental transmission of Babesia equi by Boophilus microplus. Parasitology Research, v. 84, n. 4, p. 323-327, 1998.

HAILAT, N. Q. et al. Equine babesiosis associated with strenuous exercise: clinical and pathological studies in Jordan. Veterinary Parasitology, v. 69, n. 1-2, p. 1-8, 1997. http://dx.doi.org/10.1016/ S0304-4017(96)01100-4

HEIM, A. et al. Detection and molecular characterization of Babesia caballi and Theileria equi isolates from endemic areas of Brazil. Parasitology Research, v. 102, n. 1, p. 63-68, 2007. PMid:17828553. http://dx.doi.org/10.1007/s00436-007-0726-1

HEUCHERT, C. M. S. et al. Seroepidemiologic studies on Babesia equi and Babesia caballi infections in Brazil. Veterinary Parasitology, v. 85, n. 1, p. 1-11, 1999. http://dx.doi.org/10.1016/S0304-4017(99)00108-9

KERBER, C. E. et al. Prevalence of equine Piroplasmosis and its association with tick infestation in the State of São Paulo, Brazil. Revista Brasileira de Parasitologia Veterinária, v. 18, n. 4, p. 1-8, 2009.

KOUAM, M. K. et al. Seroprevalence of equine piroplasms and host-related factors associated with infection in Greece. Veterinary Parasitology, v. 169, n. 3-4, p. 273-278, 2010. PMid:20138434. http://dx.doi.org/10.1016/j.vetpar.2010.01.011

LABRUNA, M. B. et al. Risk factors to tick infestations and their occurrence on horses in the State of São Paulo, Brazil. Veterinary Parasitology, v. 97, n. 1, p. 1-14, 2001. http://dx.doi.org/10.1016/ S0304-4017(01)00387-9

MAGALHÁES, F. E. P.; LIMA, J. D. Controle estratégico do Boophilus microplus (Canestrini, 1887) em bovinos da região de Pedro Leopoldo, Minas Gerais, Brasil. Arquivo Brasileiro de Medicina Veterinária e Zootecnia, v. 43, n. 5, p. 423-431, 1991.

MAHONEY, D. F.; ROSS, D. R. Epizootiological factors in the control of bovine babesiosis. Australian Veterinary Parasitology, v. 48, n. 5 , p. 292-298, 1972. 
MORETTI, A. et al. Prevalence and diagnosis of Babesia and Theileria infections in horses in Italy: A preliminary study. Veterinary Journal, v. 184, n. 3, p. 346-350, 2010. PMid:19394253. http://dx.doi. org/10.1016/j.tvjl.2009.03.021

NIZOLI, L. Q. et al. Frequency of seropositive equines for Theileria equi in the Southern Rio Grande do Sul State, Brazil. Parasitologia Latinoamericana, v. 63, n. 1-4, p. 46-50, 2008.

PFEIFER BARBOSA, I. et al. Epidemiological aspects of equine babesioses in a herd of horses in Brazil. Veterinary Parasitology, v. 58, n. 1-2, p. 1-8, 1995. http://dx.doi.org/10.1016/0304-4017(94)00704-G

RIBEIRO, M. F. B.; COSTA, J. O.; GUIMARÃES, A. M. Epidemiological Aspects of Babesia equi in Horses in Minas Gerais, Brazil. Veterinary Research Communications, v. 23, n. 6, p. 385-390, 1999. http://dx.doi. org/10.1023/A:1006389725759

RIBEIRO, M. F. B. et al. Babesiose equina. I. Primo-infecção de potros em área endêmica. Arquivo Brasileiro de Medicina Veterinária e Zootecnia, v. 47, n. 5, p. 641-647, 1995. PMid:10543367.

RÜEGG, S. R. et al. Age-dependent dynamics of Theileria equi and Babesia caballi infections in southwest Mongolia based on IFAT and/ or PCR prevalence data from domestic horses and ticks. Parasitology, v. 134, n. 7, p. 939-947, 2007.

SANTOS, T. M. et al. Estudo comparativo de três métodos de diagnóstico para detecção de anticorpos anti-Theileria equi em eqüinos de áreas endêmicas do estado do Rio de Janeiro. Brazilian Journal of Veterinary Research and Animal Science, v. 46, n. 6, p. 484-490, 2009.

SANTOS, T. M.; SANTOS, H. A.; MASSARD, C. L. Diagnóstico molecular de babesiose congênita em potros neonatos no estado do Rio de Janeiro, Brasil. Revista Brasileira de Parasitologia Veterinária, v. 17, p. 348-350, 2008. Suplemento 1.
SHKAP, V. et al. Seroprevalence of Babesia equi among horses in Israel using competitive inhibition ELISA and IFA assays. Veterinary Parasitology, v. 76, n. 4, p. 251-259, 1998. http://dx.doi.org/10.1016/ S0304-4017(97)00228-8

SOUZA, A. P. et al. Prevalência de anticorpos anti-Babesia equi em eqüinos no planalto catarinense. Ciência Rural, v. 30, n. 1, p. 119-121, 2000.

TEGLAS, M. et al. Ticks and tick-borne disease in Guatemalan cattle and horses. Veterinary Parasitology, v. 131, n. 1-2, p. 119-127, 2005. PMid:15936147. http://dx.doi.org/10.1016/j.vetpar.2005.04.033

TENTER, A. M.; FRIEDHOFF, K. T. Serodiagnosis of experimental and natural Babesia equi and B. caballi infections. Veterinary Parasitology, v. 20, n. 1-3, p. 49-61, 1986. http://dx.doi.org/10.1016/03044017(86)90092-0

Thompson, p. h. Ticks as vectors of equine piroplasmosis. Journal American Veterinary Medicine Association, v. 155, n. 2, p. 454-457, 1969. PMid:5816131.

UETI, M. W. et al. Ability of the vector tick Boophilus microplus to acquire and transmit Babesia equi following feeding on chronically infected horses with low-level parasitemia. Journal of Clinical Microbiology, v. 43, n. 8, p. 3755-3759, 2005. PMid:16081906. PMCid:1233951. http://dx.doi.org/10.1128/JCM.43.8.3755-3759.2005

UETI, M. W. et al. Persistently Infected Horses Are Reservoirs for Intrastadial Tick-Borne Transmission of the Apicomplexan Parasite Babesia equi. Infection and Immunity, v. 76, n. 8, p. 3525-3529, 2008. PMid:18490466. PMCid:2493223. http://dx.doi.org/10.1128/ IAI.00251-08

XUAN, X. et al. Diagnosis of equine piroplasmosis in Brazil by serodiagnostic methods with recombinant antigens. Journal of Veterinary Medical Science, v. 63, n. 10, p. 1159-1160, 2001. PMid:11714038. http://dx.doi.org/10.1292/jvms.63.1159 